\title{
High prevalence of protein tyrosine phosphatase non-receptor N22 gene functional variant R620W in systemic lupus erythematosus patients from Kuwait: implications for disease susceptibility
}

\author{
Adel M. Al-Awadhi ${ }^{1,2}$, Mohammad Z. Haider ${ }^{3^{*}}$ D, Jalaja Sukumaran ${ }^{3}$ and Sowmya Balakrishnan ${ }^{3}$
}

\begin{abstract}
Background: Systemic lupus erythematosus (SLE) is an autoimmune inflammatory disease which involves the loss of self-tolerance with hyperactivation of autoreactive T- and B-cells. Protein tyrosine phosphatase non-receptor type 22 (PTPN22) encodes for lymphoid specific phosphatase (LYP) which is a key negative regulator of T lymphocyte activation. The aim of this study was to investigate the association between PTPN22 gene functional variant R620W and systemic lupus erythematosus (SLE) by comparing its prevalence in Kuwaiti SLE patients and controls.

Methods: The study included 134 SLE patients and 214 controls from Kuwait. The genotypes of PTPN22 gene functional variant R620W were determined by PCR-RFLP and confirmed by DNA sequence analysis in both SLE patients and the controls.

Results: A relatively high prevalence of the variant $620 \mathrm{~W}$ (T-allele) of the PTPN22 gene was detected in the SLE patients from Kuwait. 35.7\% of the SLE patients had at least one variant allele (T-allele) compared to 15.9\% in the controls. A statistically significant difference was detected in the frequency of variant genotypes, $\Pi$ and $C T$ between SLE patients and the controls $(p<0.0001)$. No association was detected between the PTPN22 gene variant and the Raynaud's phenomenon, renal involvement and severity of the SLE.

Conclusions: The frequency of PTPN22 gene functional variant R620W reported in this study is amongst the highest compared to other world populations. A high prevalence of this variant in SLE patients in comparison to the healthy controls suggests its significant contribution in conferring susceptibility to SLE together with other factors.
\end{abstract}

Keywords: Protein tyrosine phosphatase non receptor-22, Systemic lupus erythematosus, Kuwait, Gene, Functional variant

\section{Background}

Systemic lupus erythematosus (SLE; MIM 152700) is a common, complex autoimmune disease with multipleorgan involvement, characterized by the production of pathogenic autoantibodies directed against cytoplasmic and nuclear cellular components [1]. It occurs predominantly in women $(>90 \%)$ and is distinguished by a loss of tolerance to self-antigens, the deposition of immune

\footnotetext{
* Correspondence: haider@hsc.edu.kw

${ }^{3}$ Department of Pediatrics, Faculty of Medicine, Kuwait University, P. O. Box 24923, 13110 Safat, Kuwait

Full list of author information is available at the end of the article
}

complexes and tissue inflammation and destruction. There are variable clinical manifestations associated with SLE which include arthralgia, rashes, alopecia, serositis, leukopenia and renal involvement [2, 3]. Unrestricted hyper-activation of the immune system may lead to the overproduction of autoantibodies, immune complex deposition, inflammatory cytokine release and eventually organ damage in SLE pathogenesis $[4,5]$. The causes of SLE are not completely understood at present. It is thought that the onset of SLE results from multifactorial etiology, involving hormonal factors, environmental triggers and genetic susceptibility [6]. Systemic autoimmune 
diseases e.g. SLE and many others are thought to share common genetic causative factors in populations of different ethnic or racial origin [7]. The involvement of major histocompatibility complex (MHC) also supported this hypothesis. However, non-MHC alleles such as a functional polymorphism (rs2476601, Arginine 620 Tryptophan, R620W) in protein tyrosine phosphatase non-receptor type 22 (PTPN22), which encodes the lymphoid PTP (LYP), was reported to be significantly associated with multiple autoimmune disorders including type 1 diabetes mellitus (T1DM; [8]), rheumatoid arthritis [9], SLE [10], Hashimoto thyroiditis [11], autoimmune thyroid disease [12] and Grave's disease [13].

The PTPN22 gene encodes a lymphoid-specific phosphatase (LYP) which has been shown to be a negative regulator of $\mathrm{T}$ cell activation [14]. The LYP contribute to $T$ cell activation by binding to the regulatory Src tyrosine kinase (Csk) [14]. It has been reported that a functional variant R620W (C1858T polymorphism) of the PTPN22 gene is located in a motif which facilitate binding of the LYP with Csk [15]. The variant form, $620 \mathrm{~W}$ carries a tryptophan residue in place of arginine (R) and affects the binding of LYP and Csk thereby disrupting the regulation of $\mathrm{T}$ cell receptor-signaling kinases e.g. Lck, Fyn and ZAP70 [14-16]. It has been postulated that the individuals carrying the variant allele $(620 \mathrm{~W})$ have an altered threshold for thymic selection, with increased numbers of autoreactive $\mathrm{T}$ cells escaping the negative selection, thus persisting in the circulation, and are prone to autoimmunity [17]. The $\mathrm{C} 1858 \mathrm{~T}$ variant has also been shown to be associated with changes in cytokine profile in SLE patients in vivo [18].

In spite of a large number of reports linking the PTPN22 gene R620W functional variant with a number of autoimmune diseases, conflicting results have appeared in the literature about its prevalence in different world populations $[3,5,7,19-22]$. In view of these diverse findings on prevalence and relationship of the PTPN22 gene R620W functional variant with SLE, we carried out this study in SLE patients from Kuwait to investigate its possible association with susceptibility to SLE in a completely different population/ethnic group.

\section{Methods}

The SLE patients were recruited from two major teaching hospitals (Amiri and Mubarak Al-Kabeer) from Kuwait. The inclusion criteria described by the American College of Rheumatology (ACR) for the diagnosis of SLE was used [23]. For the patients included in the study, a diagnosis of SLE had been made at least 23 months prior to their recruitment. The information collected from the patients included age, age-at-onset, gender, clinical manifestations associated with SLE and disease severity. The evaluation of SLE severity was made as follows: the patients were considered to have a 'mild disease' if they presented muco-cutaneous serositis, and/or arthritis and 'mild-severe' disease if the patients had hematological, renal and neurological manifestations. The renal disease associated with SLE was ascertained if the $24 \mathrm{~h}$ urine protein excretion exceeded $500 \mathrm{mg}$ or hematouria was detected ( $>5$ red blood cells/field). The hematological abnormalities associated with SLE included the presence of hemolytic anemia with reticulocytosis, or leucopenia $\left(<4000 / \mathrm{mm}^{3}\right.$ on $>$ two occasions), or lymphopenia $\left(<1500 \mathrm{~mm}^{3}\right.$ on $>$ two occasions) or thrombocytopenia $\left(<100,000 / \mathrm{mm}^{3}\right.$ in the absence of drugs). The presence of seizures or psychosis without the use of drugs or metabolic derangement were considered as the neurological presentations associated with SLE. The frequency of PTPN22 gene polymorphism in SLE patients was compared to that in a group of 214 healthy controls, matched for age and sex with the patients. The controls subjects were unrelated to the patients; were otherwise healthy and were seen at hospital outpatient clinics for minor illnesses. The controls were thoroughly examined by a specialist to ascertain their health status before recruitment in the study.

\section{Identification of genotypes for PTPN22 gene functional variant (R620W)}

The PTPN22 gene polymorphism genotypes were determined in 126 patients with SLE and 214 healthy controls. Approximately $5 \mathrm{ml}$ blood was collected from all the study subjects in appropriate tubes. For molecular studies, blood was anti-coagulated in the presence of EDTA. Total genomic DNA was isolated by using a standard method [24]. The genotypes for a non-synonymous single nucleotide polymorphism (SNP) $+1858 \mathrm{C} \rightarrow \mathrm{T} \quad(\mathrm{rs} 2476601)$ in the PTPN22 gene were identified by polymerase chain reaction-restriction enzyme fragment length polymorphism (PCR-RFLP) method as described earlier [25]. A 218 bp DNA fragment was amplified by using the primers: Forward primer: 5'-ACTGATAATGTTGCTTCAACGG-3' and reverse primer: 5-TCACCAGCTTCCTCAACCAC-3'. The PCR mixture contained 10× PCR buffer (Applied BioSystems, Foster City, USA); $1.5 \mathrm{mM} \mathrm{MgCl} ; 0.2 \mathrm{mM}$ of each of the dNTPs (deoxyribonucleotide triphosphates); 20 pmol of each primer, $250 \mathrm{ng}$ template DNA and $1 \mathrm{U}$ AmpliTaq DNA polymerase (Applied BioSystems). The amplification conditions used were denaturation at $94{ }^{\circ} \mathrm{C}$ for 5 min followed by 35 cycles of $94{ }^{\circ} \mathrm{C}$ for $30 \mathrm{~s}, 60^{\circ} \mathrm{C}$ for $30 \mathrm{~s}$ and $72{ }^{\circ} \mathrm{C}$ for $30 \mathrm{~s}$ and an extension step at $72{ }^{\circ} \mathrm{C}$ for $5 \mathrm{~min}$. The PCR product was digested with restriction enzyme RsaI at $37{ }^{\circ} \mathrm{C}$ for $90 \mathrm{~min}$. The cleavage products were analyzed by $2 \%$ agarose gel electrophoresis and visualized under UV light after staining with ethidium bromide. The 218 bp PCR product did not have an RsaI cleavage site when $1858 \mathrm{~T}$ allele $(620 \mathrm{~W}$ variant) was present and the presence of $\mathrm{C} 1858$ allele (R620) was associated with the 
presence of $176 \mathrm{bp}$ and $42 \mathrm{bp}$ cleavage products. In case of a heterozygous individual both the 218 and 176 bp bands were detected. The PCR amplicons were sequenced in a blinded manner on ABI 3130 genetic analyzer to confirm the genotypes. Genotypes could not be done in 8 SLE patients due to low volume of the blood samples obtained. The study was carried out according to the Helsinki declaration and was approved by the Institutional Ethics Committee for the protection of human subjects in research. Written informed consent was obtained from all the study subjects.

\section{Statistical analysis}

The information and the data collected from and on the study subjects was analyzed using the Statistical Package for the Social Sciences version 24 (SPSS, Chicago IL, USA). The frequencies of various genotypes and alleles detected among the SLE patients and controls were calculated by direct counting. The significance of their association was evaluated by using the Chi-square test, Fisher's Exact test and $p$-values were regarded significant when $<0.05$. The strength of association was estimated by the odds ratios which were calculated at 95\% confidence interval. The genotype distribution was also tested for Hardy Weinberg equilibrium by goodness of fit method using MSTAT software.

\section{Results}

This study included 134 SLE patients and 214 controls. In the patients group $(n=134)$, there were $123(91.8 \%)$ females and $11(8.2 \%)$ males. In the control group, there were 199 females. In the SLE patients group, the age of onset information was available in 118 cases. When stratified on the basis of age of onset, 16/118 (14\%) patients were aged between 1 and 14 years, 25/118 (21\%) between 15 and 24 years, 26/118 (22\%) between 25 and 34 years, 34/118 (29\%) between 35 and 44 years and $17 / 118(14 \%)>45$ years respectively. The data on SLE patient characteristics and clinical manifestations has been presented in Table 1. The genotype and allele frequencies of PTPN22 gene R620W functional variant amongst the SLE patients and controls have been presented in Table 2. A comparison of genotype frequency between SLE patients and the controls showed statistically significant differences in the case of CC and TT genotypes (Table 2). Similarly, the frequencies of $\mathrm{C}$ - and T-alleles were also significantly different between the SLE patients and controls (Table 2). Statistically significant differences were detected in all the three genotypes (CC, CT, TT) between females and male SLE patients $(P<0.0001$ in case of all three genotypes). However, as it is generally the case, the incidence of SLE was much higher in females than in the males in our study group. A comparison was also made for the genotype distribution on the basis of gender between the
Table 1 The characteristics of systemic lupus erythematosus (SLE) patients included in the study $(n=134)$. S.D., standard deviation; ANA, anti-nuclear antibody

\begin{tabular}{ll}
\hline Gender ratio (Female: Male) & $11: 1(123 / 11)$ \\
Mean age ( \pm S.D.), years & $36.7( \pm 9.3)$ \\
Mean age at diagnosis ( \pm S.D.), years & $30.6( \pm 8.3)$ \\
Mean disease duration (range), months & $48(6-280)$ \\
Clinical manifestations: $n(\%)$ & \\
Malar rash & $73(54.4)$ \\
Mouth ulcers & $26(19.4)$ \\
Photosensitivity & $25(18.7)$ \\
Discoid rash & $9(6.7)$ \\
Raynaud's phenomenon & $22(16.4)$ \\
Arthritis & $128(95.5)$ \\
Serositis & $29(21.6)$ \\
Renal involvement & $22(16.4)$ \\
Hematological abnormalities & $51(38)$ \\
Neurological disorders & $5(3.7)$ \\
Immunological abnormalities & \\
ANA $^{\mathrm{b}}$ & $95(70.9)$ \\
Hypertension $^{c}$ & $134(100)$ \\
\hline
\end{tabular}

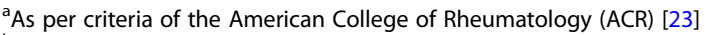

${ }^{\mathrm{b}} \mathrm{A}$ standard indirect immunofluorescence method was used for detection and ascertainment as per ACR criteria and cutoff limits [23]

${ }^{c}$ Blood Pressure $>140 / 90 \mathrm{mmHg}$ (or $>130 / 80 \mathrm{mmHg}$ in the case of renal insufficiency)

SLE patients and the controls (Table 3). For the CC and CT genotypes, the difference was statistically significant both for the females and males between the SLE patients and that in the controls. However, in the case of TT genotype, there was no significant difference between the genotype distribution between SLE patients and the controls in relation to their gender (Table 3). It may be mentioned here that in the case of controls, only $2 / 214$ subjects had a TT genotype and of these, one was male and the second a female. We did not find an association between T-allele of the PTPN22 gene functional variant and the Raynaud's

Table 2 Genotype and allele frequency of PTPN22 gene R620W functional variant in SLE patients and controls

\begin{tabular}{lllll}
\hline Genotype/ & SLE patients & $\begin{array}{l}\text { Controls } \\
\text { Allele }\end{array}$ & OR $(95 \% \text { Cl })^{\mathrm{a}}$ & $P$-value* \\
\hline CC & $81(64.3)$ & $180(84.1)$ & $0.34(0.20-0.57)$ & $<0.0001$ \\
CT & $23(18.3)$ & $32(15)$ & $1.27(0.70-2.28)$ & 0.51 \\
$\pi$ & $22(17.4)$ & $2(0.9)$ & $22.42(5.17-97.21)$ & $<0.0001$
\end{tabular}

Distribution of Alleles

C - allele $\quad$ 185/252 (73.4) $\quad 392 / 428$ (91.6) $0.25(0.16-0.39) \quad<0.0001$

$\mathrm{T}$ - allele $\quad 67 / 252(26.6) \quad 36 / 428(8.4) \quad 3.94(2.53-6.13) \quad<0.0001$

${ }^{\mathrm{a} O R}$, odds ratio at $95 \%$ confidence interval

${ }^{*} P$-values were considered significant when $<0.05$ 
Table 3 Comparison of genotypes of PTPN22 gene R620W functional variant between SLE patients group and controls stratified according to gender

\begin{tabular}{llll}
\hline Genotype/Gender & $\begin{array}{l}\text { SLE patients } \\
N(\%)\end{array}$ & $\begin{array}{l}\text { Control } \\
N(\%)\end{array}$ & $P$-value \\
\hline CC & $(N=76)$ & $(N=177)$ & $<0.001^{*}$ \\
Female & $70(92.1)$ & $115(65)$ & \\
Male & $6(7.9)$ & $62(35)$ & \\
CT & $(N=21)$ & $(N=32)$ & $<0.001^{*}$ \\
Female & $21(100)$ & $19(59.4)$ & \\
Male & $0(0)$ & $13(40.6)$ & \\
TT & $(N=21)$ & $(N=2)$ & 0.25 \\
Female & $19(90.5)$ & $1(50)$ & \\
Male & $2(9.5)$ & $1(50)$ & \\
\hline
\end{tabular}

${ }^{a}$ Chi-square test of the full cohort

* $P$-value were considered significant when $<0.05$

phenomenon, nephritis or the disease severity in SLE or any of its other manifestations in patients from Kuwait (data not shown).

\section{Discussion}

The most significant finding in this study is that a relatively high frequency of PTPN22 gene functional variant $620 \mathrm{~W}$ was detected in the SLE patients (17.4\%) compared to $0.9 \%$ in the controls. When taken together, the homozygous and heterozygous combinations of this variant allele were detected in $35.7 \%$ of the SLE patients from Kuwait. This is significantly higher than previous reports from other populations/ethnic groups. Machado-Contreras et al. [5], did not find homozygous TT genotype in any of their Mexican SLE patients, however heterozygous CT genotype was detected in 6\% Mexican SLE patients. Similarly, in a Greek study on the SLE patients from the Island of Crete, TT genotype was not detected at all while CT genotype was detected in $5.39 \%$ cases. In a report on SLE patients from Egypt [26], the authors could not detect a homozygous TT genotype but did find heterozygous CT genotype in 52.5\% SLE cases. A comprehensive PTPN22 gene association study [3], reported minor allele frequency (MAF) of $11.9 \%$ in European Americans, 2.1\% in African Americans and $7.6 \%$ in Hispanics. This study also reported that the association of the $1858 \mathrm{~T}$ allele with SLE was greater in European American patients with familial SLE (11.9\%) compared to the sporadic SLE (8.2\%). A study from Poland [21] found a positive association between the variant allele of the PTPN22 gene and SLE. Aksoy et al. [22] did not find the TT genotype in Turkish SLE patients while the CT genotype was detected in $7 \%$ cases. Another study, on white Americans [27], reported that the TT genotype was detected in $2.5 \%$ SLE patients while the CT genotype was found in $20.4 \%$ SLE patients. In this study, the overall riskallele frequency was found to be $12.67 \%$ compared to
8.64\% in the white American controls. Positive association between PTPN22 gene polymorphism and SLE susceptibility has been reported from Sweden [28] and Spain [29]. Namjou et al. [29] reported findings from genotyping of ten SNPs in four large multi-ethnic populations and using their results in conjunction with data from the Hap-Map project, concluded that SLE association with PTPN22 was largely accounted for by the R620W variant (rs2476601) in individuals of European ancestry [21-26, 30, 31]. A strong North-South gradient in the risk-allele frequency has also been reported in Europe [32].

Recent reports provide information on the mechanism of R620W functional variant of the PTPN22 gene [33-38]. In the light of postulated scheme for involvement of R620W variant in the molecular mechanism of autoimmunity [33, 34], our data from SLE patients from Kuwait supports and highlights its role as a significant determinant of the SLE susceptibility. However, it may also be appropriate to mention that the genetic factors which contribute to susceptibility/protection to develop SLE most likely involve multiple genes. Kuwait is a small country located in the North of Arabian Gulf. The population of Kuwait is quite diverse; Kuwaiti Arabs constitute nearly $45 \%$ of the population. There is a high incidence of consanguinity (54\%; [39]), which often results in familial clustering of common chronic disorders. The incidence of diseases with autoimmune etiology such as type 1 diabetes mellitus is amongst the highest in the region and bordering with the high-incidence countries of the world [40, 41]. The original settlers of Kuwait were immigrants from Najd, an area that now constitute eastern and central Saudi Arabia. The ethnic origin of Kuwaiti Arabs is quite varied; $50 \%$ are of Arab origin, some are Bedouins and nearly $50 \%$ are immigrants [42]. The Arabs residing in most of the Gulf countries are a result of an admixture with other populations such as Persians, Turks, South Asians, Europeans and Africans [42]. The genotype frequency of variant $620 \mathrm{~W}$ reported in our SLE patient group from Kuwait is amongst the highest (TT, 17.4\% and combined TT and CT in $35.7 \%$ patients) compared to any of the other populations/ethnic groups. This can possibly be due to a cumulative effect of unique genetic/ethnic background along with a very high rate of consanguinity (54\%) in the Kuwaiti population and can at least in part, explain the high incidence of autoimmune diseases including SLE in the country.

\section{Conclusions}

The frequency of PTPN22 gene functional variant R620W reported in this study is amongst the highest compared to other world populations. A high prevalence of this variant in SLE patients in comparison to controls suggests its significant contribution in conferring susceptibility to SLE along with other factors. 


\section{Abbreviations}

Csk: Src tyrosine kinase; DNA: Deoxyribonucleic acid; dNTP: Deoxyribonucleotide triphosphate; LYP: Lymphoid specific phosphatase; MHC: Major histocompatibility complex; PCR: Polymerase chain reaction; PTPN22: Protein tyrosine phosphatase non-receptor type 22; R: Arginine; RA: Rheumatoid arthritis; RFLP: Restriction fragment length polymorphism; SLE: Systemic lupus erythematosus; SNP: Single nucleotide polymorphism; T1DM: Type 1 diabetes mellitus; W: Tryptophan

\section{Acknowledgements}

The assistance of hospital staff who helped in sample and data collection is thankfully acknowledged. We thank Mrs. Asiya Ibrahim for help in statistical analysis.

\section{Funding}

The project was funded by Kuwait University and the funding body had no role in study design, collection and analysis of data and writing the manuscript.

\section{Availability of data and materials}

The clinical data on individual study subjects will not be made available in order to protect the participant's identity. All the relevant data has been included in the manuscript.

\section{Authors' contributions}

All authors have read the manuscript and approve its submission for publication. AMA contributed in study design, recruitment and clinical evaluation of the study subjects and in writing the manuscript. MZH along with AMA conceived and designed the study, supervised the laboratory/ analytical procedures, analyzed clinical and laboratory data and wrote the manuscript. JS and SB Carried out laboratory and experimental studies and compiled the data.

\section{Ethics approval and consent to participate}

This project was approved by the Committee for Protection of Human Subjects in Research by the Kuwait University, Faculty of Medicine (Ref. FOM/213-02). The study has been carried out strictly according to the guidelines of the Committee and as per Helsinki Declaration. Written informed consent was obtained from the study subjects for participation in this study.

\section{Consent for publication}

Not applicable.

\section{Competing interests}

The authors declared that they have no competing interests.

\section{Publisher's Note}

Springer Nature remains neutral with regard to jurisdictional claims in published maps and institutional affiliations.

\section{Author details}

${ }^{1}$ Department of Medicine, Faculty of Medicine, Kuwait University, Jabriya, Kuwait. ${ }^{2}$ Rheumatic Disease Unit, Al-Amiri Hospital, Dasman, Kuwait. ${ }^{3}$ Department of Pediatrics, Faculty of Medicine, Kuwait University, P. O. Box 24923, 13110 Safat, Kuwait.

Received: 10 September 2017 Accepted: 1 March 2018 Published online: 16 March 2018

\section{References}

1. Choi J, Kim ST, Craft J. The pathogenesis of systemic lupus erythematosus - an update. Curr Opin Immunol. 2012;24:651-7.

2. Lahita RG. Systemic lupus erythematosus. 4th ed. New York, USA: Academic Press; 2004.

3. Kaufman KM, Kelly JA, Herring BJ, Adler AJ, Glenn SB, et al. Evaluation of the gene association of the PTPN22 R620W polymorphism in familial and sporadic Systemic lupus erythematosus. Arthritis Rhem. 2006;54:2533-40.

4. Anaya J-M, Shoenfeld Y, Cervera R. Systemic lupus erythematosus-2014. Autoimmune Dis. 2014, 274323. DOl: https://doi.org/10.1155/2014/274323.

5. Machado-Contreras JR, Munoz-Valle JF, Cruz A, Salazar-Camarena DC, Marin-Rosales M, et al. Distribution of PTPN22 polymorphisms in SLE from western Mexico: correlation with mRNA expression and disease activity. Clin Exp Med. 2016;16:399-406.
6. O'Neill S, Cerevera R. Systemic lupus erythematosus. Best Pract Res Clin Rheumatol. 2010;24:841-55.

7. Tang L, Wang Y, Zheng S, Bao M, Zhang Q, Jianming L. PTPN22 polymorphisms, but not R620W, were associated with the genetic susceptibility of systemic lupus erythematosus and rheumatoid arthritis in a Chinese Han population. Hum Immunol. 2016;77:692-8.

8. Aarnisalo J, Treszl A, Svec P. Reduced CD4(+) T cell activation in children with type 1 diabetes carrying the PTPN22/Lyp 620Trp variant. J Autoimmun. 2008;31:13-21.

9. Rodriguez-Rodriguez WR, Tai R, Topless S, Steer MF, Gonzales-Escribano A, et al. The PTPN22 R263Q polymorphism is a risk factor for rheumatic arthritis in Caucasian case-control samples. J Arthritis Rheum. 2011;63:365-72.

10. Baca V, Velazquez-Cruz R, Salas-Martinez G, Espinosa-Rosales Y, Saldana-Alvarez L, et al. Association analysis of the PTPN22 gene in childhood-onset systemic lupus erythematosus in Mexican population. Genes Immun. 2006;7:693-5.

11. Criswell LA, Pfeiffer KA, Lum RF, Gonzales B, Novitzke J, et al. Analysis of families in the multiple autoimmune disease genetics consortium (MADGC) collection: the PTPN22 620W allele associates with multiple autoimmune phenotypes. Am J Hum Genet. 2005;76:561-71.

12. Wu H, Cantor RM, Cunninghame DS, Graham DS, Lingren CM, et al. Association analysis of the R620W polymorphism of the protein tyrosine phosphatase PTPN22 in systemic lupus erythematosus patients with autoimmune thyroid disease. Arthritis Rheum. 2005;52:2396-2402.

13. Heward M, Brand OJ, Barrett JC, Carr-Smith JA, Franklyn SC, et al. Association of PTPN22 haplotypes with Grave's disease. J Clin Endocrinol Metab. 2007;92:685-90.

14. Bottini N, Musumeci L, Alonso A, Rahmouni K, Nika M, et al. A functional variant of lymphoid tyrosine phosphatase is associated with type 1 diabetes. Nat Genet. 2004:36:337-8.

15. Cloutier JF, Veillette A. Cooperative inhibition of T-cell antigen receptor signaling by a complex between a kinase and a phosphatase. J Exp Med. 1999;198:111-21.

16. Bogovich AB, Carlton VE, Honigberg LA, Schrodi SJ, Chokkalingam AP, et al. A missense single nucleotide polymorphism in a gene encoding a protein tyrosine phosphatase (PTPN22) is associated with rheumatoid arthritis. Am J Hum Genet. 2004;75:330-7.

17. Bottini N, Vang T, Cucca F, Mustelin T. Role of PTPN22 in type 1 diabetes and other autoimmune diseases. Semin Immunol. 2006;18:207-13.

18. Kariuki SN, Crow MK, Niewold TB. The PTPN22 C1858T polymorphism is associated with skewing of cytokine profiles towards high interferon-alpha activity and low tumor necrosis factor alpha levels in patients with lupus. Arthritis Rheum. 2008:58:2818-23.

19. Eliopoulos E, Zervou Ml, Andreou A, Dimopoulou N, Cosmidis N, et al. Association of the PTPN22 R620W polymorphism with increased risk for SLE in the genetically homogeneous population of Crete. Lupus. 2011;20(5):501-6.

20. Maalej A, Chabchoub G, Glikmans E. Association study of PTPN22 gene with Rheumatoid Arthritis in the Tunisian population. Eur J Hum Genet. 2006:14(Suppl.1):326

21. Piotrowski P, Lianeri M, Wudarski M, Lacki JK, Jagodzinski PP. Contribution of the R620W polymorphism of protein tyrosine phosphatase non-receptor 22 to systemic lupus erythematosus in Poland. Clin Exp Rheumatol. 2008:26(6):1099-102

22. Aksoy R, Duman T, Keskin O, Duzgun N. No association of PTPN22 R620W gene polymorphism with rheumatic heart disease and systemic lupus erythematosus. Mol Biol Rep. 2011;38:5393-6.

23. Tan EM, Cohen AS, Fries JF, Masi AT, McShane DJ, et al. The 1982 revised criteria for the classification of systemic lupus erythematosus. Arthritis Rheum. 1982;25:1271-7.

24. Sambrook J, Freitsch EF, Maniatis T. Molecular Cloning: A Laboratory Manual. 2nd ed. New York, USA: Cold Spring Harbor Laboratory; 1989.

25. Saccucci P, Del Duca E, Rapini N, Verrotti A, Piccinini S, et al. Association between PTPN22 C1851T and type 1 diabetes: a replication in continental Italy. Tissue Antigens. 2008;71:234-7.

26. Moez P, Soliman E. Association of PTPN22 gene polymorphism and systemic lupus erythematosus in a cohort of Egyptian patients: impact on clinical and laboratory results. Rheumatol Int. 2012;32:2753-8.

27. Kyogoku C, Langefeld CD, Ortman WA, Lee A, Selby S, et al. Genetic association of the R620W polymorphism of protein tyrosine phosphatase PTPN22 with human SLE. Am J Hum Genet. 2004:75:504-7.

28. Reddy MV, Johansson M, Sturfelt G, Jinsen A, Gunnarsson I, et al. The R620W C/T polymorphism of the gene PTPN22 is associated with SLE independently of the association of PDCD1. Genes Immun. 2005;6:658-62. 
29. Namjou B, Kin-Howard X, Sun C, Adler A, Chung SA, et al. PTPN22 association in systemic lupus erythematosus (SLE) with respect to individual ancestry and clinical sub-phenotypes. PLoS One. 2013;8:e69404.

30. Lea W, Lee Y. The association between the PTPN22 C1858T polymorphism and systemic lupus erythematosus: a meta-analysis update. Lupus. 2011;20:51-7.

31. Orozco G, Sanchez E, Gonzalez-Gay MA, Lopez-Nevot MA, Torres B, et al. Association of a functional single-nucleotide polymorphism of PTPN22 encoding lymphoid protein phosphatase, with rheumatoid arthritis and systemic lupus erythematosus. Arthritis Rheum. 2005;52:219-24.

32. Manjarrez-Orduno N, Marasco E, Chung SA, Katz MS, Kiridly JF, et al. CSK regulatory polymorphism is associated with systemic lupus erythematosus and influence B-cell signaling and activation. Nat Genet. 2012;44:1227-30.

33. Behrens TW. Lyp breakdown and autoimmunity. Nat Genet. 2011;43:821-2.

34. Zhang J, Zahir N, Jiang Q, Miliotis H, Heyrand S, et al. The autoimmune diseaseassociated PTPN22 variant promotes calpain-mediated Lyp/Pep degradation associated with lymphocyte and dendritic cell hyperresponsiveness. Nat Genet. 2011:43:902-7.

35. Vang T, Congia M, Macis MD, Masumeci L, Orru V, et al. Autoimmune-associated lymphoid tyrosine phosphatase is a gain-of-function variant. Nat Genet. 2005;37:1317-9.

36. Arechiga AF, Habib T, He Y, Zhang X, Zhang ZY, et al. Cutting edge: the PTPN22 allele variant associated with autoimmunity impairs B cell signaling. J Immunol. 2009;182:3343-7.

37. Dai X, James RG, Habib T, Singh S, Jackson S, et al. A disease-associated PTPN22 variant promotes systemic autoimmunity in murine models. J Clin Invest. 2013:123:2024-36

38. Cambier JC. Autoimmunity risk alleles: hot spots in B cell regulatory signaling pathways. J Clin Invest. 2013;123:1928-31.

39. Al-Awadi SA, Moussa MA, Naguib KK, Farag TI, Teebi AS, et al. Consanguinity among the Kuwaiti population. Clin Genet. 1985;27:483-6.

40. Shaltout AA, Moussa MAA, Qabazard M, Abdella N, Karvonen M, et al. Further evidence for the rising incidence of childhood type-1 diabetes in Kuwait. Diabet Med. 2002;19(6):522-5.

41. Rasoul MA, Al-Mahdi M, Al-Kandari H, Dhaunsi GS, Haider MZ. Low serum vitamin $\mathrm{D}$ status is associated with high prevalence and early onset of type-1 diabetes mellitus in Kuwaiti children. BMC Pediatr. 2016;16:95. https://doi.org/10.1186/s12887-016-0629-3.

42. Teebi AS, Farag TI. Population dimensions in Arab World. In: Teebi AS, Farag TI, editors. Genetic disorders among Arab populations. Oxford, UK: Oxford University Press; 1997. p. 29-51.

\section{Submit your next manuscript to BioMed Central and we will help you at every step:}

- We accept pre-submission inquiries

- Our selector tool helps you to find the most relevant journal

- We provide round the clock customer support

- Convenient online submission

- Thorough peer review

- Inclusion in PubMed and all major indexing services

- Maximum visibility for your research

Submit your manuscript at www.biomedcentral.com/submit

) Biomed Central 